


\title{
SPRAYING WITH "BLACK LEAF 40" TO CONTROL ONION THRIPS.
}

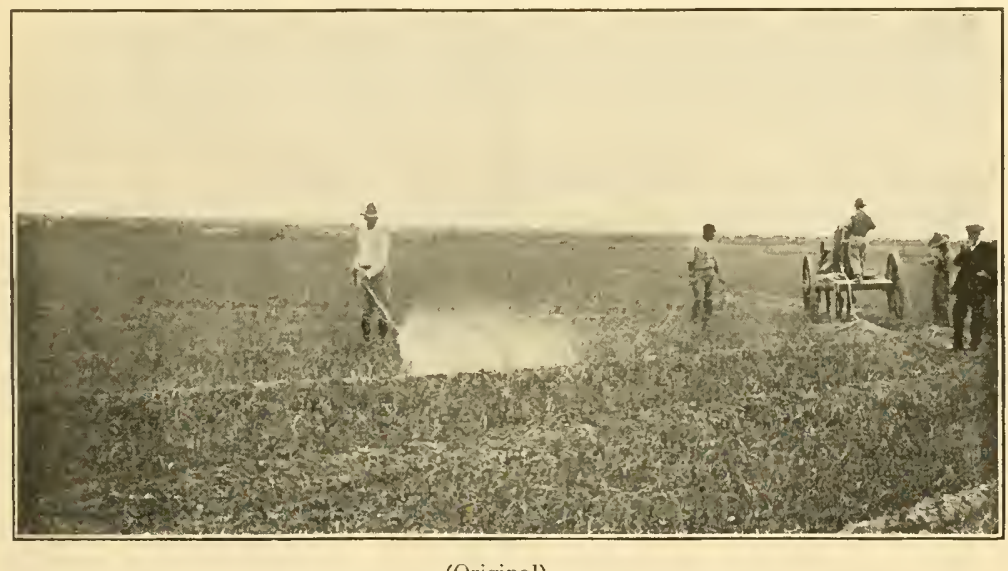

(Original)

Practieal method of spraying onions with a barrel spraver.

\section{The Kentucky Tobacco Product Company}

\author{
LOUISVILLE, KY., U. S. A.
}




\title{
Spraying with "Black Leaf 40" for the Control of the Onion Thrips.
}

\begin{abstract}
Onions, in common with other truck erops, often "fail." Such "failures" were at one time considered "natural" and a matter of course. It was thought that nothing could be done to avoid the injury and if the crop did "fail", the only thing left for the grower was to hope for better luck next time. This condition is rapidly disappearing. Progressive growers now realize that each failure is clue to certain definite causes, some of which are preventable.

A considerable proportion of such failures is caused by the onion thrips, known as "onion louse," a small, narrow, active insect. When young, it is light yellow and is generally found deep in the fork of the onion plant. When it beemes a fully developed, winged insect, it is darker and is found on the leaf of the plant as well as in the fork.
\end{abstract}

\section{HABITS OF THE ONION THRIPS:}

This very small insect lays its eggs just beneath the surface of the leaves or stem. It usually takes two to three weeks from the time the eggs hatch until the developing insects themselves lay eggs, but cooler weather may lengthen this period. These thrips continue to multiply as long as the weather and food permit. From these facts it is evident that though few thrips are present at any one time, they may occur in destructive numbers later.

The onion thrips feeds on a large variety of garden, field and ormamental plants, the most common being cabbage, turnip, cauliflower, cantaloupe, melon, squash, cucumber and tomato.

\section{THRIPS INJURY TO THE PLANT:}

The grower first notices a "silvering" of the onion tops. Upon examination he discovers this silvering to be due to scratches on the leaves caused by the thrips. Growers frequently call this condition "white blight."

The next evidence is the eurling, twisting and drying of the leaves, their color changing to brown. In fact, a badly infested field may look as if the tops had been entirely burned over. The crop may be so injured as to amount to total destruction; or the bulbs may be so reduced in size as to be hardly worth $\because$ pulling. A sudden hot or cold spell finds injured plants unprepared to withstand $\therefore$ the change, often resulting in considerable additional injury.

\section{METHODS OF CONTROL.}

The directions here given are based on actual control work conducted on commereial onion plantings. The control of the onion thrips is practical, economical and profitable. Follow the directions given in this bulletin, do the work thoroughly and faithfully and your efforts will be well worth while.

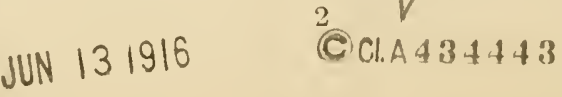




\section{FORMULA:*}

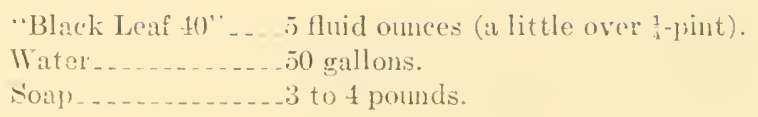

The larger amount of soap is to be used where the water is hard. Note particularly that enough soap should be present to produce suds.

To dissolve the soap, slice it thin and boil it in a small amount of water. Keep stirring. Cottun seed oil soap or any good laundry soap will do, provided it is not raustic. Soft soap is ey+n more preferable, as it dissolver more readily. The soap is userl as a "spreader" to enable the "Black Leaf 40 " to penetrate into the fork, enver the plants and to prevent the formation of drops which may roll off and leave the plant and insects dry.

\section{"BLACK LEAF 40":}

Is a conecntrated solution of nicotine sulphate guaranteed to contain $40 \%$ nicotine br weight. It kills thrips and similar insects when brought into contact with their bodies. Being highly coneentrated, it is easy to handle and ship and requires very little room for storage. A two-pound tin makes over 250 gallons of spray for the onion thrips. Mixing readily with water, "Black Leaf 40 " does not clog spray nozzles, nor does it injure foliage when used as recommended.

"Black Leaf 40" has been widely tested. The directions are based on the recommendations of the United States Department of Agriculture and State Experiment stations, in aldition to other field experiments.

In the report of Insects Injurious to the Onion Crop, which appeared in the Year Book of the U. S. Department of Agriculture for 1912, occurs the following statement, on page 324 :

"Plants sprayed with nieotine sulphate combination present a striking contrast to those which are not so treated. In Maryiand, near the Distriet of Columbia, a single spraying of nicotine sulphate gave similar results, the plants doing better and the insects being killed to a larger extent than by the use of other insecticides. Terosene emulsion has sometimes proved a failure in Colorado and elsewhere and is, moreover, difficult to make with hard or alkaline water."

\section{WHEN TO SPRAY:}

\section{Start Your Campaign as Soon as Possible.}

Do not delay until the onion tops begin to turn brown. It may then be too late. When a grower states that he lost his crop, "all in a few days," it is evidence that the thrips have been in his field ali season.

Here are some of the reasons why the spraying should be done early.

The earlier you siray the less time it takes to cover an acre.

The earlier you spray, the less material is necessary per acre; later, as the plants beeome larger, more spraying material is needed.

The earlier you spray, the easier it is to hit the insects. Later, when the tops are large and bent over, it is much more difficult to reach them with the spray.

The earlier you spraly, the fewer insects there are to control. For every insect present early in the season, later there may be hundreds or thousands. Destruction of the ancestors would prevent development of the descendants.

\footnotetext{
* Good results have been obtained with 4 ounces "Black Leaf 40 " to 50 gallons.
} 


\section{SPRAYING CAMPAIGN SHOULD BEGIN IN THE SEED BED:}

Many serious attacks in commereial onion fields may be traced hack to the seed bed. If you are growing your own plants, see that the thrips are controlled in the seed bed. It may be advisable to spray several times at intervals of seven to ten days.

\section{BEFORE TRANSPLANTING:}

Before transplanting, dip the plants in the same formula as used in spraying. The I. S. Department of Agriculture recommends dipping about a week before planting time, and then dipping twice at planting time. Many thrips are brought into the fields on the transplants. An ordinary hucket may be used, the sets plaeed in a wire basket, dipped, and allowed to drain.

\section{IN SPRAYING ONION FIELDS:}

Don't forget that although spraying prevents considerable injury, it can not remove injury after it has occurred.

Don't experiment with unknown or untried material.

Don't expeet one application to clean up your field; make at least three.

Don't fail to spray thoroughly and with good pressure (not less than 150 bounds).

\section{Remember, you must force the spray down between the leaves.}

Don't wait until the green tops begin to die and then expect to save the erop. Spraying will pay at this time and may save part of the erop, but the best results follow earlier applications.

Don't forget that you can control the thrips in young onions more effectively and more economieally than later in grown plants.

\section{REMARKS ON EQUIPMENT:}

For a small bed, such as the kitehen garden, ete., of very young onions, a knapsack or small compressed air sprayer may be satisfactory. However, we recommend, especially for large beds, the use of an outfit sufficient to develop good pressure. In the seed bed and on young onions, satisfactory results may be obtained with a wheelbarrow-tractor wherein the wheel works the pump, or a handeart sprayer, which is an ordinary metal tank holding a good hand pump, mounted on a two-wheel handeart.

In young onions, both the wheelbarrow and handeart sprayer can be guided hetween the rows without difficulty and without damage. In using outfits of this kind, the nozzles should be adjusted so that when the outfit is in operation, the nozzle will be but slightly above the top of the plants. These small outfits develop mueh less pressure than the larger outfits, hence full advantage should be taken of what pressure is developed, and this is obtained by keeping the nozzle as near the plant as possible. 


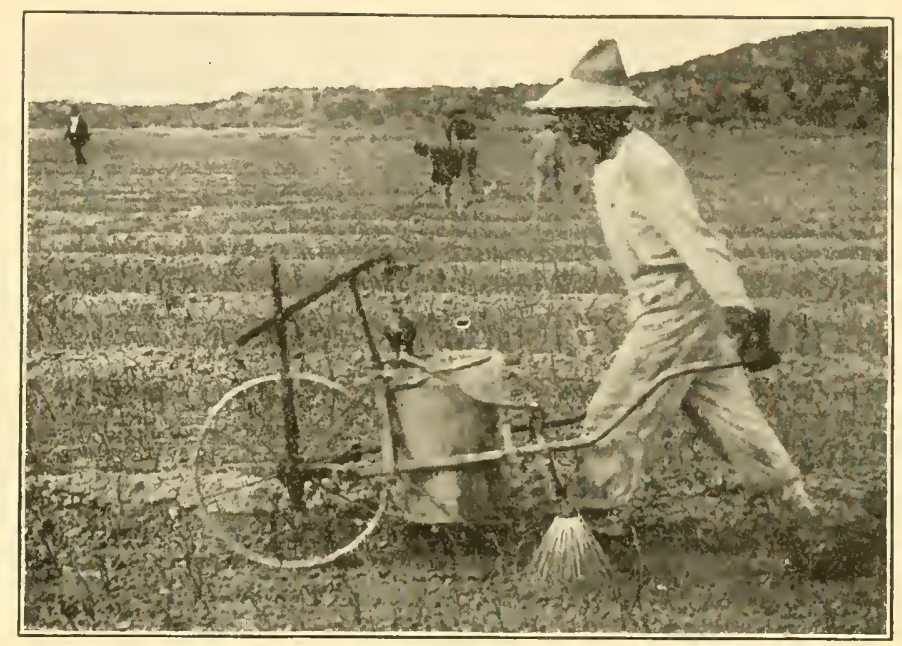

(Original)

Spraying very young onions with a wheel barrow-traetor sprayer.

The wheelbarrow-tractor outfit should not have more than two nozzles, one on each side of the outfit. Eash nozzle should cover only one row. More than two nozzles may be put on the handeart outfit, if the pump is sufficient for maintaining a good pressure for each nozzle.

The above outfits may be found useful for young to half-grown onions; however, even for young onions, the barrel (preferably a double action pump capable of maintaining 150 pounds pressure), or a power outfit will give the best results; and these outfits are absolutcly essential for effective work on older onions. The small outfits with fixed nozzles do not develop enough pressure to drive the spray into the fork of the older plants.

\section{THE BEST TYPE OF OUTFIT:}

Use a good barrel or power ontfit with a long hose which, if necessary, may be as long as 100 feet or more. The hose is equipped with an extension rod (such as is used in orchard spraying), about 12 fect long, with a Bordeaux or wide angle dise nozzle attached. The man doing the spraying walks down one row and swings the rod across the rows in front of him, spraying first one side as far as the rod will reach and then the other; in this way covering a swath about twenty-five feet in width. It may be necessary to have a man at the outfit to play out and pull in the hose, as the man handling the spray rod goes out or comes back, (sce illustration on page one). It is possible, in many plantings, to spray the whole bed without being obliged to haul the spray machine over it, by having a length of hose half the length of the onion rows. In such case, half the length of the rows is sprayed from one side, then the ontfit moves to the opposite side of the field from where the other half of the field is sprayed in the same manner. Where onion rows are too long, it may be necessary to make an extra trip through the field in order to cover the full length of the rows. In such case, there may be a slight amount of trampling unless a lane for the outfit has previously been provided for. 


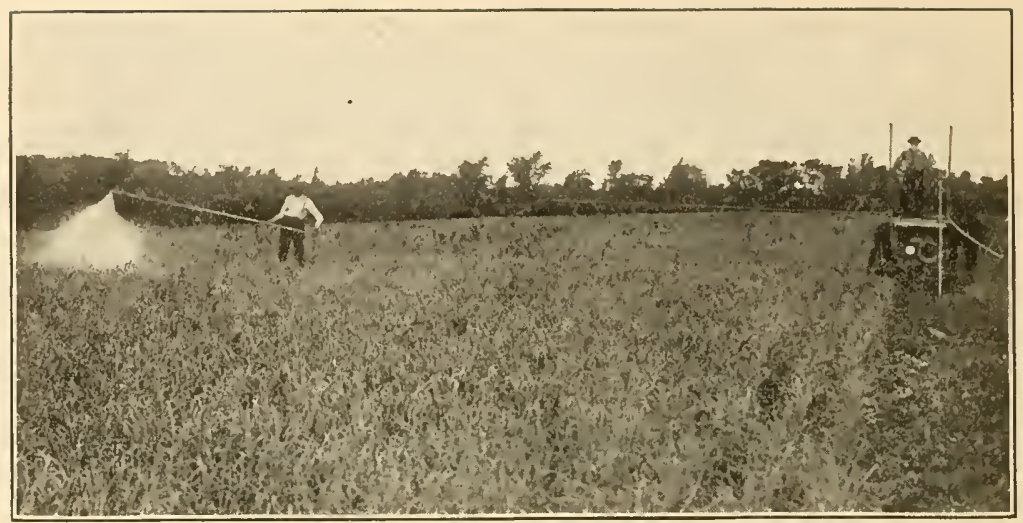

Using a power outfit with boom attached for onion spraying.

For this photograph, the nozzle was held high to show spray. In actual work the nozzle should, of course, be held much closer to the plants.

Good results have been obtained by using an ordinary power orchard sprayer with a boom attachment on each side extending perhaps twenty feet on each side. At the end of this boom, attach about fifteen feet of hose and extension rod-the longer the better. With an equipment of this kind on each side of the machine, each outfit can spray a șath of from 70 to 90 feet by driving through the field. The spraying is done across the rows by a man on each side. Each man works away from the outfit as far as the hose and boom will permit and then works in toward the outfit. (See illustration above).

The nozzles should discharge the spray at right angles to the rod, so that there is a direct spray downward, as the rod is held horizontally. The nozzle should be swept elose down across each row and should occasionally be turned so that the plants will also get a rlischarge of spray on the side, in addition to the regular spray into the fork of the plant. It may be found advantageous to have two wide angle nozzles, one pointing down and forward, and the other down and backward, by which arrangement all sides of the plants receive an application of spray.

\section{NUMBER OF APPLICATIONS:}

Though good results may follow one or two applications; it is frequently essential to have not less than three. Apply every week or two, depending on the weather. More applications will be required in hot than in cold weather. One application will kill all the thrips the spray hits and wets. But remember that more thrips will hatch later and another application must be made to get the following generation and those individuals that were not hit the previous time.

\section{SPECIAL ANNOUNCEMENT.}

The Kentucky Tobacco Product Company maintains a Field Department of trained entomologists. Submit your problems to them. In the matter of planning campaigns with individual growers, communities, organizations, County Agents, etc.; assistance will be gladly given. 


\section{TABLE OF DILUTION FOR ONION THRIPS.}

"Black Leaf 40"

Water.

About $\frac{3}{4}$ teaspoonful

1 gallon.

1 fluid ounce (S small teaspoonfuls)

12 gallons.

2 fluid ounces ( $\frac{1}{3}$ pint)

25 gallous.

5) fluid ounces (a little over 1 pint)

50 gallons.

10 fluid ounces (a little over $\frac{1}{2}$ pint) .

100 gallons.

\section{PRICES OF "BLACK LEAF 40”.}

10-pound tin, makes 12S0 gallons of spray, S10.75

2 -pound tin, makes 256 gallons of spray, 2.50

$\frac{1}{2}$-pound tiu, makes $\quad$ i 1 gallons of spray, .75

1-oz. bottle, makes s gallone of spray, 25

PUBLISHED BY

THE KENTUCKY TOBACCO PRODLCT CONPANY.

Incorporated

I.OUISVILLE, KENTUCKY, U. S. A.

Form 219. $1-16-6$.

Ianufacturers of "Black Leaf 40." 


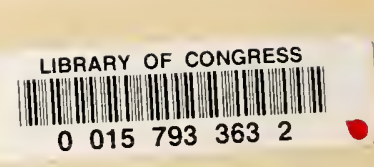

